\title{
nature
}

\section{Victory for political scientists}

The reinstatement of evolution in the Kansas school curriculum is not only good news for science and for the students. It is a timely demonstration that researchers can and must act politically when their values are at stake.

U niversity of Kansas cell biologist Matthew Buechner remembers a surreal moment during the campaign to return the teaching of evolution to his state's school classrooms. US Senator Sam Brownback (Republican) came to the Lawrence, Kansas, campus in the spring for a meeting, where Francis Collins, director of the Human Genome Project, praised the senator for being "instrumental" in boosting the National Institutes of Health budget. But Brownback was also supporting the leader of the Kansas Board of Education, Linda Holloway, a fellow Republican who a year ago stripped evolution from the state standards for kindergartens.

On the one hand, the senator is helping to provide federal money for research that affirms evolution; on the other, he is catering to rightwing political groups that seek to deny children knowledge of the results of that research. Welcome to the peculiar world of American politics. For Buechner, a political neophyte who had joined Kansas Citizens for Science to help ensure the teaching of evolution in classrooms, it was a defining moment. He wrote to Brownback seeking an explanation. Pointing out that "the entire Human Genome Project is $100 \%$ based" on evolution, and highlighting the need to compare DNA from different species, Buechner wrote: "This is why the project spent hundreds of millions of dollars to obtain the complete genomes of bacteria, yeast, worms and fruitflies." He has still had no response.

That may change, because Buechner and other Kansas scientists played an integral role in ousting from the school board the Republicans - including Holloway - who deleted evolution studies (see page 552). Kansas Citizens for Science leaders are savouring the taste of victory. Furthermore, Kansas Governor Bill Graves decried the school board's vote to eliminate evolutionary teaching a year ago, calling it one of Kansas' most embarrassing moments. But the
Republican avoided taking a public stand in the school board race until the final days of the Republican primary campaign, when he was finally persuaded to endorse the pro-evolution stance. Graves tried to side-step endorsements in the election, says Caroline McKnight, Kansas City leader of the Mainstream Coalition, a state-wide nonpolitically partisan group that supports the teaching of evolution. But the pro-science movement wouldn't let him.

Scientists should remember this lesson from the Kansas campaign: raise your voices, and make politicians listen. It worked in New Mexico, when scientists played a prominent role in keeping evolution in the state school curriculum. And it has worked again in Kansas, where the state school board is expected to reinstate evolution after the general election in November when there will be a pro-evolution majority. According to McKnight, scientists "had to be dragged kicking and screaming" to join the effort. They believed the answer was to educate people, failing to see that it was a political issue. But, says McKnight, researchers were bemused by their discovery of political power - "like some scientific discovery".

Researchers everywhere should take note. In most scientifically active countries one can find politically influential campaigns or policies that are perceived by scientists to undermine what they stand for and their capacity to do research. Alongside a greater dialogue, there is an increasing need for researchers, although probably much against their inclinations, to be considered as a non-partisan political force in such debates. Their learned societies and their institutions and employers can provide only limited support. It takes those with strong personal commitment, and a willingness for some professional sacrifice, to take up the political cudgels. The Kansas victory is just one demonstration that it is worth it.

\section{Tobacco industry vs science}

A report on the tobacco industry's activities against scientific assessment is powerful support for transparency.

"W e believe in operating with trust, integrity and respect, both as individuals and as a company." "Our aim is to be known as a responsible company in an industry seen as controversial." These quotes are from the websites of, respectively, Philip Morris and British American Tobacco. In the light of a report published last week (see http://filestore.who.int/ who/ home/tobacco/tobacco.pdf), such statements must refer to another planet. The report describes the tobacco industry's attempts to undermine science-based assessments of risks associated with tobacco. Valuably, it highlights how significantly the scientific community and regulatory processes were exposed to the threat of manipulation.

The 247-page report documents the results of a trawl by an expert panel appointed by the World Health Organization (WHO) through confidential documents released by the tobacco companies as a result of recent litigation. It describes in detail the case of a scientific consultant who, according to this report, concealed his links with the industry while taking part in a review of pesticide use and cancer that could have restricted tobacco agriculture. The report now raises questions about the resulting safety standards.

On a much larger scale, the industry planned to undermine a study of the environmental risks of tobacco smoke by the WHO's International Agency for Research on Cancer. The report documents partially successful attempts to delay the study, to establish contacts with scientists involved, to conduct and promote "counter research", to manipulate the public's response to the study's conclusions via government and the media, and to cancel or influence the expected monograph. In the end, says the report, the industry failed to undermine the study, whose results were published in 1998, but succeeded in manipulating media accounts and obtaining confidential information.

This is just a small selection of the tobacco industry's attempts to weaken tobacco control described in the report. Its readers might well conclude that it is testimony to the strength of the regulatory and scientific process that both have emerged as little damaged as they have. But the WHO, other agencies concerned with tobacco, and scientific institutions and publications must strengthen their guard against conflicts of interest. Watch this space. 